\title{
ENERGY RECOVERY FROM IMMOBILISED CELLS OF SCENEDESMUS OBLIQUUS AFTER WASTEWATER TREATMENT
}

\author{
M. Gomes San Juan*, F. Ometto**, R. Whitton*, M. Pidou, B. Jefferson* and R. Villa**. \\ ${ }^{*}$ Cranfield University, CWSI, Cranfield, UK \\ **Scandinavian Biogas Fuels AB, Linköping, SE \\ † Corresponding author
}

Anaerobic digestion, biogas, wastewater treatment

\section{Summary}

Biomethane batch test of alginate beads and beads with algae at different stages of utilisation in the wastewater treatment plants showed that immobilised $S$. obliquus yield similar biogas and biomethane than freely suspended algae (between $60.51 \pm 4.19$ and $82.32 \pm 2.17 \mathrm{~mL} \mathrm{~g}$ $1 \mathrm{VSadd}$ ) and that a pre-treatment stage was not necessary for the digestion process.

\section{Introduction}

Microalgae have shown to be able to remediate nutrients effectively from secondary wastewater, their use in WWT processes and biogas production by anaerobic digestion (AD) was first reported by Golueke at al. (1957) and Oswald and Golueke (1960). At the time, the authors' main conclusion was that, although the algae removed nutrients to satisfactory levels, the overall process was not economically and energetically viable, and regrettably this is still the case today (Ometto, 2014b). Process intensification can be achieved using cells entrapped into a resin or gelatinous media, such as alginate or synthetic polymers ( $3.3 \mathrm{~g} \cdot \mathrm{L}-1 \mathrm{DW})$. RuizMarín et al. (2010 and 2011) and Whitton et al (2014) all demonstrated good nutrient removals with immobilised algae. However, even when immobilised, the inclusion of microalgae in the WWT process for nutrients absorption could only be justified if biomass is processed to recover energy.

Of the currently available biomass-to-energy technologies, gasification, thermochemical liquefaction, direct combustion and anaerobic digestion (AD), AD provides the most feasible process for large scale application which, depending on the chemical composition, has the potential to yield up to $800 \mathrm{mlCH}_{4} \mathrm{gVS}^{-1}$ (Heaven et al., 2011). However, microalgae species have the ability to resist microbial degradation, their structure and chemical composition identified the cell wall as the main limiting factor to microbial degradation (Atkinson et al., 1972; Burczyk et al., 1999). High energy (thermal and ultrasound) and low energy (mechanical and biological) pre-treatments can be used to: (1) degrade the cell wall, (2) release AOM and hence (3) enhance methane production (Alzate et al., 2012; González-Fernández et al., 2012b; Cho et al., 2013a).

Batch anaerobic digestion experiments were used to assess the effect of thermal and biological pre-treatment on the methane production of immobilised Scenedesmus obliquus, after nutrients removal process.

\section{Material and methods}

Algae culture and immobilisation

The S. obliquus (276/42) culture was obtained from the Culture Collection for Algae and Protozoa (CCAP), (Oban, UK). Microalgae was cultured in batch in $100 \mathrm{~L}$ tanks containing 50 L Jaworski media as reported in Ometto et al., 2014c and b. Immobilisation conditions were reported in Whitton et al., 2016.

\section{Batch anaerobic digesters}


Five different substrates were analysed in this work. Four types of algal beads; 1) Blank Beads with no algal biomass, with only the alginate matrix (BB), 2) Clean Algal Beads (CA), fresh beads containing microalgae cells imbedded in the alginate matrix that have not been used for wastewater remediation, 3) Beads after 6 days of wastewater treatment (6-d UA), 4) Beads at 10 days usage (10-d UA), and 5) the residual algal sludge at the end of the columns experiment (AS). All substrates were characterised in terms of TS and VS before and after anaerobic digestion (APHA, 2005). The four types of beads were pre-treated and the degradation of their structure was analysed. The biomethane test was carried out on both untreated and enzymatically treated substrates. The batch tests were done as reported Ometto et al., 2014b

\section{Pre-treatments (thermal and biological)}

Thermal pre-treatment of the beads biomass was achieved using an autoclave at $121^{\circ} \mathrm{C}$ and 1.06 bar for $30 \mathrm{~min}$. The solid content (VS and TS) and the SCOD were measured in duplicate before and after treatment (Ometto, 2014c). Only beads pre-treated with E1 and E2 at $150 \mathrm{U}$ $\mathrm{mL}^{-1}$ (equivalent to $7.5 \mathrm{U} \mathrm{kg}^{-1} \mathrm{TS}$ ) were used for the biomethane test.

The enzymes used in the study experiments are summarised in Table 1.

Table 1. List of enzyme used for the biomass pre-treatment

\begin{tabular}{|c|c|c|c|}
\hline Enzyme & $\begin{array}{c}\text { Commercial } \\
\text { name }\end{array}$ & Composition & Conditions tested \\
\hline $\mathrm{E} 1$ & DepolTM 40L & $\begin{array}{l}\text { Cellulase } 1,200 \mathrm{U} \mathrm{g}^{-1} \\
\text { +Endogalactouronase } 800 \mathrm{U} \mathrm{g}^{-1}\end{array}$ & $25,50,150,250$, and $350 \mathrm{U} \mathrm{mL}^{-1}$ \\
\hline E2 & $\begin{array}{l}\text { LipomodTM } \\
957\end{array}$ & $\begin{array}{l}\text { Esterase } 3,600 \mathrm{U} \mathrm{g}^{-1} \\
\text { +Protease } 90 \mathrm{U} \mathrm{g}^{-1}\end{array}$ & $\begin{array}{l}150 \text { and } 250 \mathrm{U} \mathrm{mL}^{-1} \\
\left(7.5 \mathrm{U} \mathrm{kg} \mathrm{kS}^{-1} \mathrm{TS}\right.\end{array}$ \\
\hline E3 & $\begin{array}{l}\text { LipomodTM } \\
166 \mathrm{P}\end{array}$ & Esterase $5,220 \mathrm{U} \mathrm{g}^{-1}$ & $\begin{array}{l}150 \text { and } 250 \cup \mathrm{mL}^{-1} \\
\left(7.5 \mathrm{U} \mathrm{kg}^{-1} \mathrm{TS}\right)\end{array}$ \\
\hline E4 & Lipase LT & Lipase $100,000 \mathrm{U} \mathrm{g}^{-1}$ & $\begin{array}{l}150 \text { and } 250 \cup \mathrm{mL}^{-1} \\
\left.7.5 \cup \mathrm{kg}^{-1} \mathrm{TS}\right)\end{array}$ \\
\hline E5 & $\begin{array}{c}\text { Accelerase } \\
1500\end{array}$ & $\begin{array}{l}\text { Endoglucanase } 2200 \mathrm{U} \mathrm{g}^{-1} \\
+\beta \text {-Glucosidase } 450 \mathrm{U} \mathrm{g}^{-1}\end{array}$ & $\begin{array}{l}150 \text { and } 250 \cup \mathrm{mL}^{-1} \\
\left(7.5 \mathrm{U} \mathrm{kg}^{-1} \mathrm{TS}\right)\end{array}$ \\
\hline
\end{tabular}

\section{Results and discussion}

The calculation of the biogas yield for the untreated beads were $29.73 \pm 2.17 \mathrm{~mL}$ for DS; $160.12 \pm 6.66 \mathrm{~mL}$ for Blank Beads (BB); $124.27 \pm 15.56 \mathrm{~mL}$ for (Clean algae beads) CA; $179.54 \pm 12.43 \mathrm{~mL}$ for 6-d (Untreated Algae Beads) UA; $254.17 \pm 6.71 \mathrm{~mL}$ for 10-d UA; 175.51 $\pm 32 \mathrm{~mL}$ for AS; and $217.82 \pm 24 \mathrm{~mL}$ for control with cellulose. Ometto et al. (2014c) obtained a biogas yield of $265.28 \pm 10 \mathrm{~mL} \mathrm{g-1} \mathrm{VSadd,} \mathrm{which} \mathrm{is} \mathrm{similar} \mathrm{to} \mathrm{the} \mathrm{10-d} \mathrm{UA} \mathrm{value..} \mathrm{10-d} \mathrm{UA}$ beads demonstrated a similar behaviour to suspended $S$. obliquus microalgae for biogas and biomethane production. The 10-d beads were weak and misshapen due to degradation of the alginate matrix hence exposing the immobilised cells, this is likely to be the reason for the similarity to suspended calls. The lower performance of 6-d UA, and the even lower of CA, was likely due to the lower biomass concentration as a result of the reduced contact time with wastewater and reduced growth (105 microalgae cells in CA beads, $5.3 \times 105$ cells in 6 -d UA, and $7 \times 105$ cells in 10-d UA). Results are reported in Figure 1.

Biogas yield of enzymatically pre-treated beads, resulted in enzymes and dosage: 1316.3 $121.60 \pm 32.18 \mathrm{~mL}$ (for BB+E1); $125.27 \pm 24.01 \mathrm{~mL}$ (for CA+E1); $142.41 \pm 3.44 \mathrm{~mL}$ (for 6-d $U A+E 1$ ); $271.16 \pm 3.04 \mathrm{~mL}$ (for 6-d UA+E2); 20 and $135.83 \pm 9.72 \mathrm{~mL}$ (for 10-d UA+E1). The cumulative biogas values are lower than those reported by Ometto (2014c) for suspended $S$. obliquus with the same $\pm 224 \mathrm{~mL} \mathrm{~g}^{-1}$ VSadd with E1 at $150 \mathrm{U} \mathrm{mL}^{-1}$ and $986.34 \pm 201 \mathrm{~mL} \mathrm{~g}^{-1}$ VSadd with E2 at $150 \mathrm{U} \mathrm{mL}^{-1}$. About the $\mathrm{CH}_{4}$ production, excepting $\mathrm{BB}$, all substrates yielded a very similar amount of biomethane after 33 days. Results are reported in Figure 2. 


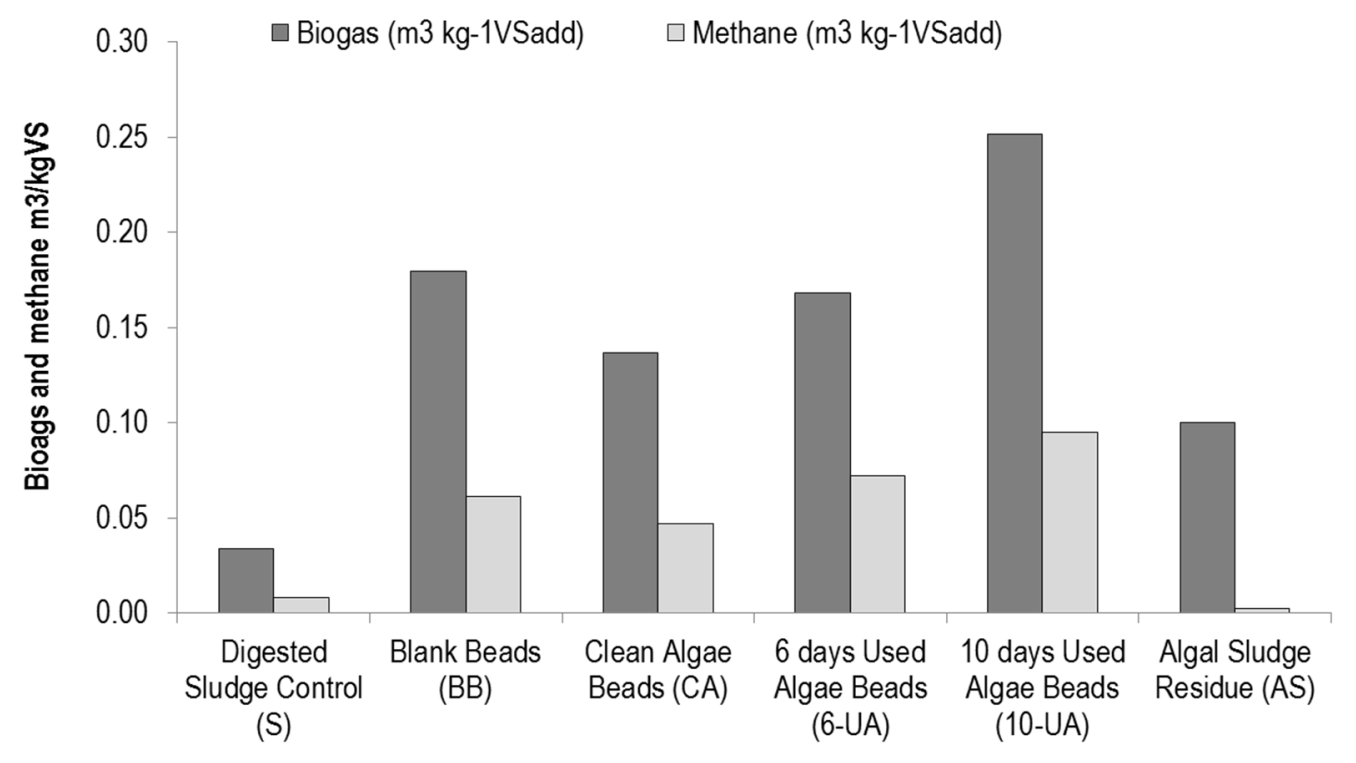

Figure 1. Biogas and biomethane production in batch tests of untreated exhausted algae beads after nutrient removal.

ESEM pictures (Figure 3) of the untreated and treated beads showed that higher biodegradability was observed after enzymatic pre-treatment in terms of alginate structure damage. The granules visible on the outside of the treated beads are likely to be non-dissolved enzymes. 

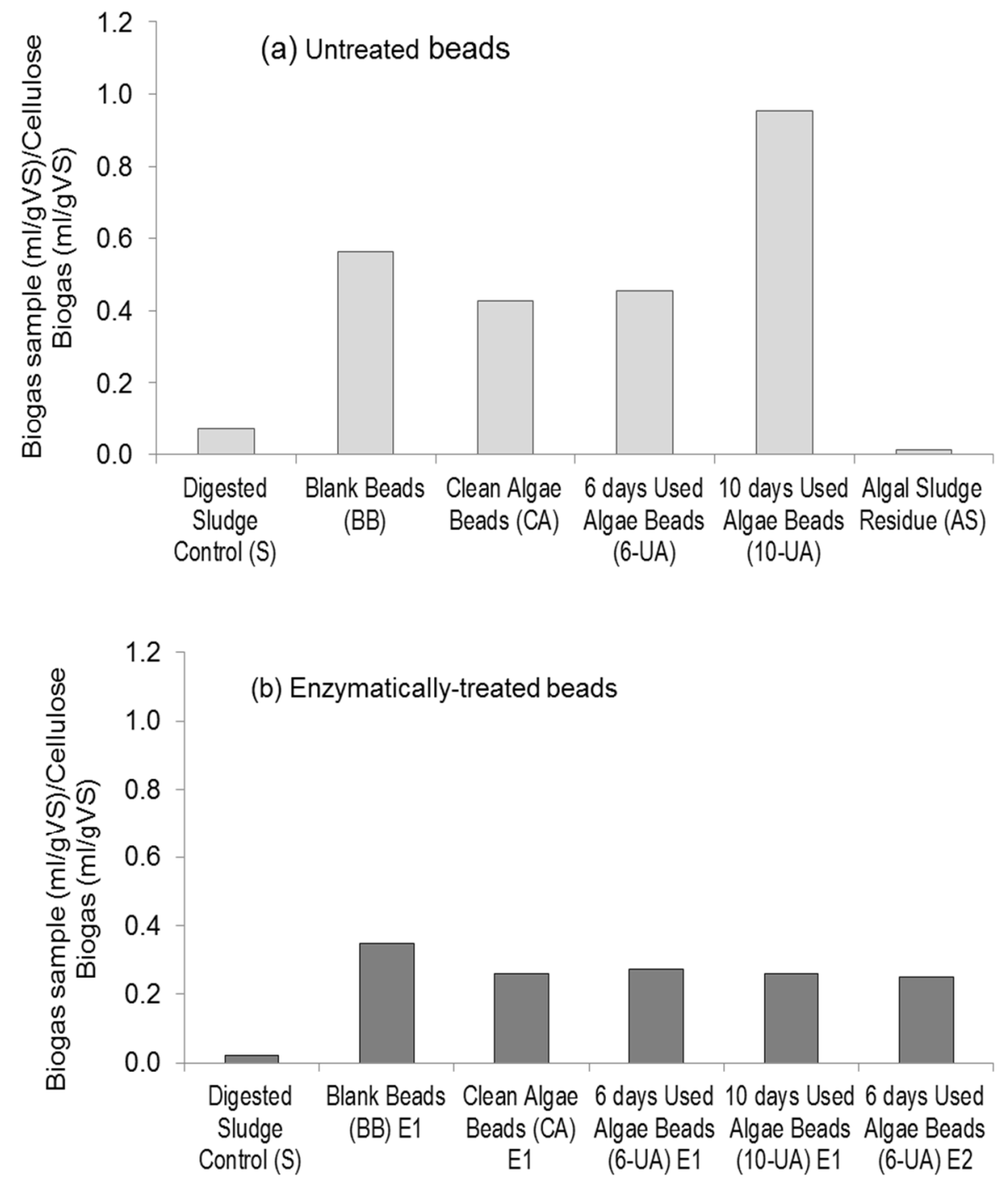

Figure 2. Comparison of biogas production of treated (enzymatically) and untreated algae beads in batch tests. Biogas values have been normalised using the value obtained for cellulose (reference material) to allow comparison amongst different batches. 
BB untreated

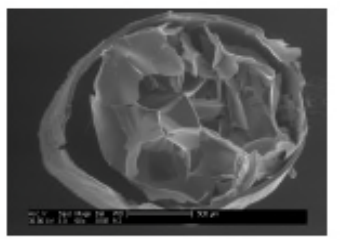

CA untreated

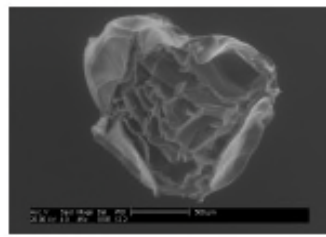

6-d UA untreate

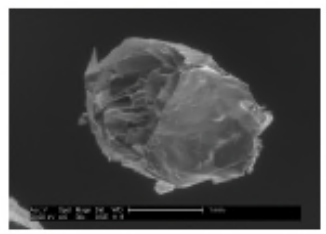

10-d UA untreated

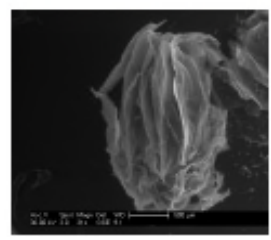

BB enzymatically pre-treated
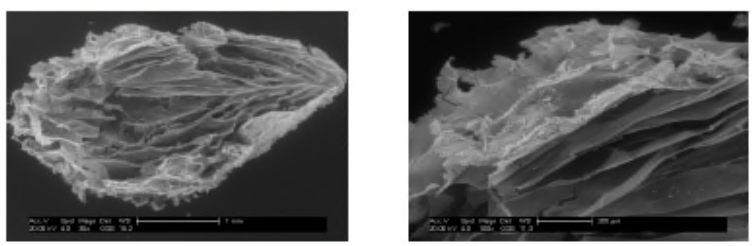

CA enzymatically pre-treated
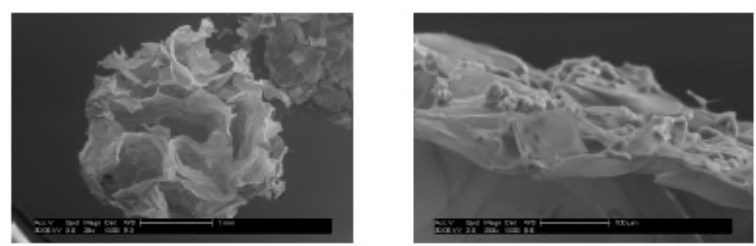

6-d UA enzymatically pre-treated
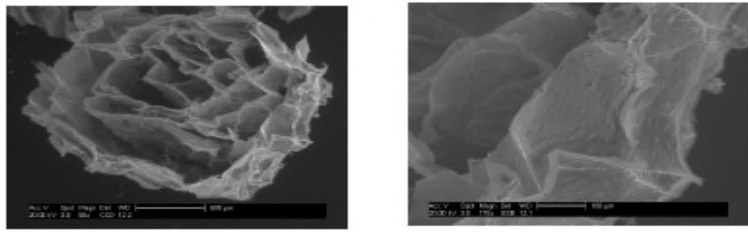

10-d UA enzymatically pre-treated
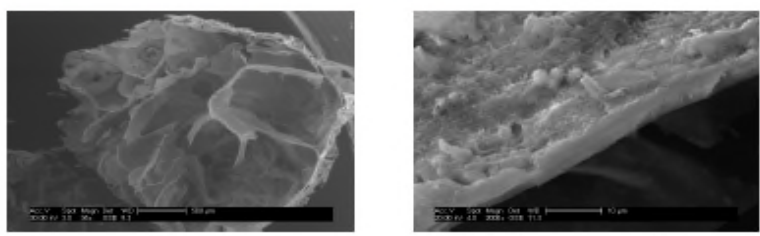

Figure 3. ESEM pictures of treated (enzymatically) and untreated algae beads.

\section{Conclusions}

- Biogas can be produced from microalgae (S. obliquus) after wastewater treatment process

- Immobilised S. obliquus used for wastewater treatment can produce similar biogas and biomethane yields compared to freely suspended S.obliquus.

- Specific biogas and methane values of microalgae beads gave industry-acceptable values (up to $80 \%$ ).

- Pre-treatment of the algae beads to increase biogas production did not give positive results. This indicates an inhibition during $A D$, probably caused by the released of calcium alginate (bead matrix).

\section{References}

Alzate, M. E., Muñoz, R., Rogalla, F., Fdz-Polanco, F., Perez-Elvira, S. I. (2012) Biochemical methane potential of microalgae: influence of substrate to inoculum ratio, biomass concentration and pretreatment. Bioresour. Technol. 123, 488- 494.

Atkinson, A.W.J., Gunning, B.E.S., John, P. C. L. (1972) Sporopollenin in the cell wall of Chlorella and other algae: Ultrastructure, chemistry, and incorporation of 14C-acetate, studied in synchronous cultures. Planta

Burczyk, J., Śmietana, B., Termińska-Pabis, K., Zych, M., Kowaloski, P. (1999) Comparison of nitrogen content amino acid composition and glucosamine content of cell walls of various chlorococcales algae. Phytochemistry. 51, 491-497. 
Cho, S., Park, S., Seon, J., Yu, J., Lee, T. (2013) Evaluation of thermal, ultrasonic and alkali pretreatments on mixed-microalgal biomass to enhance anaerobic methane production. Bioresour. Technol. 143, 330-336.

Golueke, C.G., Oswald, W.J., Gotaas, H.B. (1957) Anaerobic digestion of algae. Appl. Biotechnol. 5, 47-55.

González-Fernández, C., Sialve, B., Bernet, N., Steyer, J.P. (2012). Thermal pretreatment to improve methane production of Scenedesmus biomass. Biomass and Bioenergy. 40, 105-111.

Heaven, S., Milledge, J., Zhang, Y. (2011) Comments on Anaerobic digestion of microalgae as a necessary step to make microalgal biodiesel sustainable. Biotechnol. Adv. 29(1), 164-167.

Ometto, F., Pozza, C., Whitton, R., Smyth, B., Torres, A.G., Henderson, R.K., Jarvis, P., Jefferson, B., Villa R. (2014a). The impact of replacing air bubbles with microspheres for the clarification of algae from low celldensity culture. Wat. Res. 53, 168-179.

Ometto, F., Whitton. R., Coulon, F., Jefferson, B., Villa, R. (2014b). Improving the Energy Balance of an Integrated Microalgal Wastewater Treatment Process. Waste Biomass Valor. 5, 245-253.

Ometto, F., (2014c) Microalgae to energy: biomass recovery and pre-treatments optimization for biogas production integrated with wastewater nutrients removal. PhD Thesis. Cranfield University.

Ometto F., Quiroga G., Psenǐckă P., Whitton R., Jefferson B. and Villa R. (2014d) Impacts of microalgae pretreatments for improved anaerobic digestion: thermal treatment, thermal hydrolysis, ultrasound and enzymatic hydrolysis. Wat. Res. 65: 350-361.

Oswald, W.J., Golueke, C.G. (1960) Biological transformation of solar energy. Adv Appl Microbiol. 2, $223-62$.

Ruiz-Marin, A., Mendoza-Espinosa, L.G., Stephenson, T., 2010. Growth and nutrient removal in free and immobilized green algae in batch and semicontinuous cultures treating real wastewater. Bioresour. Technol. 101, 58-64.

Ruiz-Marín, A., Mendoza-Espinosa, L.G., Sánchez-Saavedra, M. (2011) Photosynthetic characteristics and growth of alginate-immobilized Scenedesmus obliquus. Agrociencia. 45, 303-313.

Whitton R., Le Mevel A., Pidou M., Ometto F., Villa R., Jefferson B.(2016) Influence of microalgal N and P composition on wastewater nutrient remediation. Wat. Res. 91, 371-378. 